\title{
A new species of Petrocosmea (Gesneriaceae) from Myanmar
}

\author{
D.J. Middleton ${ }^{1}$, Thant $\mathrm{Shin}^{2} \&$ Y. Baba ${ }^{3}$ \\ ${ }^{1}$ Singapore Botanic Gardens, National Parks Board, \\ 1 Cluny Road, 259569 Singapore \\ david_middleton@nparks.gov.sg \\ ${ }^{2}$ Forest Research Institute, 15013 Yezin, \\ Zayarthiri Township, Naypyidaw, Myanmar \\ ${ }^{3}$ Auckland War Memorial Museum Tāmaki Paenga Hira, \\ Private Bag 92018, Auckland 1142, New Zealand
}

\begin{abstract}
The new species Petrocosmea villosa D.J.Middleton from Shan State, Myanmar is described. It is most similar to Petrocosmea kerrii Craib, P. crinita (W.T.Wang) Z.J.Qiu and P. heterophylla B.L.Burtt in Petrocosmea sect. Deinanthera but differs particularly in inflorescence structure, inflorescence indumentum and in the long calyx lobes.
\end{abstract}

Keywords. Petrocosmea crinita, Petrocosmea heterophylla, Petrocosmea kerrii, Petrocosmea sect. Deinanthera, Shan State

\section{Introduction}

The genus Petrocosmea Oliv. consists of between 47 species (Wen, 2019) and 55 species (GRC 2021, continuously updated) in southwestern China, northeastern India, Myanmar, Thailand and Vietnam. Craib (1919) recognised two sections within the genus based on the relative sizes of the upper and lower lips of the corolla. Wang (1985) added a third section, Petrocosmea sect. Deinanthera W.T.Wang, to include the species with the anthers constricted at the apex to form a short thick beak. Qiu et al. (2015) suggested, however, that the existing sectional treatment of the genus insufficiently reflects its morphological diversity and phylogeny.

A specimen, Baba et al. 103535, collected from Myanmar, Shan State, Lomkok Mountain at $1106 \mathrm{~m}$ elevation, has the anther shape characteristic of Petrocosmea sect. Deinanthera, which has about nine species altogether and which is most diverse in nearby northern Thailand (Wang, 1985; Middleton \& Triboun, 2010). It is not one of the known species of this section so is here described as new.

Only two other species of Petrocosmea are currently recorded from Myanmar, P. kerrii Craib and P. kingii (C.B.Clarke) Chatterjee (Kress et al., 2003), although it would be surprising if $P$. bicolor D.J.Middleton \& Triboun, $P$. formosa B.L.Burtt, $P$. heterophylla B.L.Burtt, P. pubescens D.J.Middleton \& Triboun and possibly even $P$. umbelliformis B.L.Burtt were not also eventually to be found in the country given their collection localities in Thailand close to the Myanmar border. 


\section{New species}

Petrocosmea villosa D.J.Middleton, sp. nov.

Similar to Petrocosmea kerrii and P. crinita (W.T.Wang) Z.J.Qiu in the shape and colour of the corolla but differs from both in having both sessile and petiolate leaves (petiolate only in P. kerrii and P. crinita), longer calyx lobes (11-12 mm long in $P$. villosa, $1.5-4 \mathrm{~mm}$ long in $P$. kerrii and $P$. crinita) and more flowers in the inflorescence than P. kerrii (8-12 in P. villosa, 1-4 in P. kerrii). Also similar to Petrocosmea heterophylla in having two types of leaves and in the shape and colour of the corolla but differs in the sessile leaves being smaller (to $2 \mathrm{~cm}$ long in $P$. villosa, to $5.5 \mathrm{~cm}$ long in $P$. heterophylla), the villous hairs in $P$. villosa (pubescent rather than villous in $P$. heterophylla), inflorescence more congested in P. villosa (lax in P. heterophylla), and longer calyx lobes (11-12 mm long in P. villosa, 4.5-8 $\mathrm{mm}$ long in P. heterophylla). - TYPE: Myanmar, Shan State, Taunggyi Township, Lomkok mountain and pagoda,

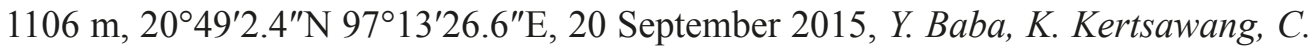
Kilgour, S. Ruchisansakun, P. Srisanga, P.P. Hnin \& Yo El 103535 (holotype MBK; isotype RAF n.v.). (Fig. 1)

Rosulate herb with two types of leaves: a cluster of sessile leaves and long-petiolate leaves. Sessile leaves few, c. 2 cm long, densely villous. Petiolate leaves: petioles 2.5$8 \mathrm{~cm}$ long, densely pubescent; blades ovate, $1.9-13.2 \times 1.1-6.6 \mathrm{~cm}, 1.4-2.1$ times as long as wide, base rounded to weakly cordate, apex acuminate, margin denticulate, 4-7 pairs of ascending secondary veins, pubescent above and beneath, more densely so on venation. Inflorescences few per plant, with 8-12 flowers, 8-10 cm long, umbelliform with flowers crowded at apex, densely white villous throughout; peduncle $5.5-8 \mathrm{~cm}$ long; pedicels 3-7.5 mm long. Calyx pale green, weakly 2-lipped, the lower 2 lobes free, the upper 3 lobes fused at base for $2 \mathrm{~mm}$, all lobes narrowly triangular, apices caudate, margins crenulate towards apex, densely villous outside, glabrous inside; lower lobes $12 \times 2.1 \mathrm{~mm}$, upper lobes 11-12 × 2.4-2.9 mm, lateral ones slightly falcate. Corolla c. $1 \mathrm{~cm}$ long, tube short and limb spreading resulting in a flat-faced flower, white tinged yellow at base of upper lip, with orange-yellow markings at base of lower lip, outside pubescent on lobes and with sessile glands, inside with short hairs at throat and with sessile glands at base of upper lip; tube c. $3 \mathrm{~mm}$ long; limb 2-lipped; upper lip 2-lobed, c. $7 \mathrm{~mm}$ long, lobes c. $7 \times 7 \mathrm{~mm}$, sinus between them c. $3.5 \mathrm{~mm}$ deep; lower lip 3-lobed, c. $8.5 \mathrm{~mm}$ long, lateral lobes c. $5.5 \times 6 \mathrm{~mm}$, middle lobe c. $4 \times 5 \mathrm{~mm}$. Stamens inserted at base of corolla tube, anthers pressed face to face but not coherent in rehydrated flowers; filaments c. $1 \mathrm{~mm}$ long, c. $1.1 \mathrm{~mm}$ wide; anthers 2, c. $4.7 \times 2.5 \mathrm{~mm}$, apical beak c. $1 \mathrm{~mm}$ long; staminodes 3, c. $0.7 \mathrm{~mm}$ long. Pistil c. $9.5 \mathrm{~mm}$ long, eglandular pubescent throughout; ovary c. $4 \mathrm{~mm}$ long; style and stigma c. $5.5 \mathrm{~mm}$ long. Fruit a plagiocarpic capsule on elongated pedicels, $5.5-6 \mathrm{~mm}$ long.

Distribution. Only known from the type locality.

Ecology. Edge of evergreen forest on limestone karst. 

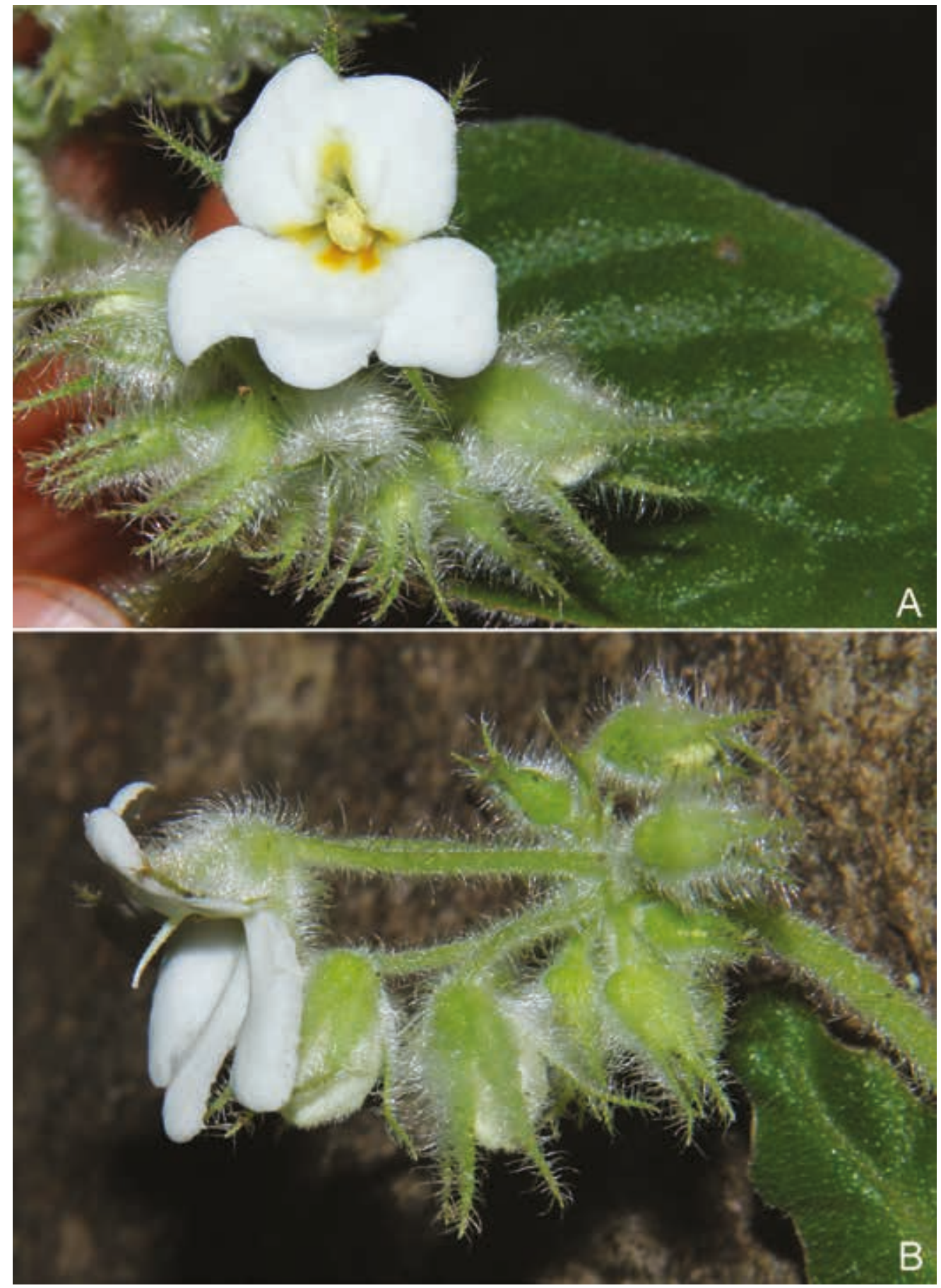

Fig. 1. Petrocosmea villosa D.J.Middleton. A. Flower front view. B. Flower side view. (Photo: S. Ruchisansakun) 
Etymology. The specific epithet refers to the dense hair covering on the inflorescence.

Provisional IUCN conservation assessment. Data Deficient (DD) according to the IUCN Red List Categories and Criteria (IUCN Standards and Petitions Committee, 2019). As it is currently only known from the type collection and its distribution and population size are insufficiently known, it is assessed here as DD. The collection locality is not within a protected area but there is a pagoda near the collection locality, affording protection from large scale destruction (such as mining).

ACKNOWLEDGEMENTS. We thank the collectors of the type and the collectors in turn are grateful to Dr Nyi Nyi Kyaw, Director General, Forest Department, Ministry of Natural Resources and Environmental Conservation for his continuous support for floristic research in Myanmar. The field work was conducted under an MoU between the Myanmar Forest Department and Kochi Prefecture Makino Botanical Garden (MBK). The curatorial staff of the herbarium at MBK are thanked for the loan of material to Singapore Botanic Gardens (SBG). We thank Dr Saroj Ruchisansakun for the photographs used in Fig. 1.

\section{References}

Craib, W.G. (1919). Revision of Petrocosmea. Notes Roy. Bot. Gard. Edinburgh 111: 269-275. GRC 2021 (continuously updated). Gesneriaceae Resource Centre. http://padme.rbge.org.uk/ GRC/. Royal Botanic Garden Edinburgh. Accessed 16 Aug. 2021.

IUCN Standards and Petitions Committee (2019). Guidelines for Using the IUCN Red List Categories and Criteria. Version 14. Prepared by the Standards and Petitions Committee. Available from: http://iucnredlist.org/documents/RedListGuidelines.pdf.

Kress, W.J., De Filipps, R.A., Farr, E. \& Kyi, D.Y.Y. (2003). A checklist of the trees, shrubs, herbs, and climbers of Myanmar. Contr. U.S. Natl. Herb. 45: 1-590.

Middleton, D.J. \& Triboun, P. (2010). Two new species of Petrocosmea (Gesneriaceae). Thai For. Bull., Bot. 38: 42-47.

Qiu, Z.J., Lu, Y.X., Li, C.Q., Dong, Y., Smith, J.F. \& Wang, Z.Y. (2015). Origin and evolution of Petrocosmea (Gesneriaceae) inferred from both DNA sequence and novel findings in morphology with a test of morphology-based hypotheses. BMC Pl. Biol. 15-167: 1-19.

Wang, W.T. (1985). The second revision of the genus Petrocosmea (Gesneriaceae). Acta Bot. Yunnan. 7(1): 49-68.

Wen, F. (2019). Petrocosmea weiyigangii (Gesneriaceae), a new species from a limestone cave in southern China. Gard. Bull. Singapore 71: 175-183. 